\title{
Linguagens
}

\section{DISCURSO, VARIAÇÃO E LETRAMENTOS NA ESCOLA: OS MODOS \\ DE DIZER NA EDUCAÇÃO BRASILEIRA DE NORTE A SUL PELAS CÂMERAS DO DOCUMENTÁRIO “PRO DIA NASCER FELIZ"}

\author{
Francisco Renato Lima (UFPI) \\ Vanessa Raquel Soares Borges (UFPI) \\ Catarina de Sena Sirqueira Mendes da Costa (UFPI)
}

\begin{abstract}
RESUMO: Este texto adota como objeto de estudo o documentário "Pro dia nascer feliz", de João Jardim, com o objetivo de analisar a questão da realidade da educação brasileira, a partir dos aspectos teóricos de discurso, variação e letramentos que constituem os modos de ver e dizer o mundo, através da visão de mundo dos personagens. Parte-se de uma pesquisa bibliográfica de caráter qualitativo, baseada nos estudos da sociolinguística educacional (BORTONI-RICARDO, 2004/2005) e em alguns fundamentos teórico-legais do ensino da Língua Portuguesa. A análise evidencia problemas que emergem, principalmente das condições socioculturais dos protagonistas da história - professores e alunos -, os quais dizem, a seu modo, as reais condições que vivenciam na escola, a qual se tornou um espaço de conflitos, disputas e divergências sociais, que estão imbricadas na fala de cada sujeito.
\end{abstract}

PALAVRAS-CHAVE: Discurso. Variação linguística. Letramentos na escola.

ABSTRACT: This text adopts as object of study the documentary "Pro dia nascer feliz", work of João Jardim, with the objective of analyzing the reality of Brazilian education, from the theoretical aspects of discourse, variation and literacy that constitute the ways of seeing and saying the world through the world view of the characters. It is based on a qualitative bibliographical research, based on the studies of educational sociolinguistics (BORTONI-RICARDO, 2004/2005) and on some theoretical-legal foundations of Portuguese language teaching. The analysis reveals problems that emerge, mainly from the sociocultural conditions of the protagonists of history - teachers and students - who say, in its way, the real conditions they experience in school, which became an area of conflict, disputes and social differences, which are embedded in the speech of each subject.

KEYWORDS: Speech. Linguistic variation. Literacy at school.

\section{CONSIDERAÇÕES INICIAIS}

"Há ou não motivo para se revoltar? Deixemos aberta a discussão. Insurge-se, é um fato; [...] Talvez. Questão de realidade, certamente. [...]”. (Michel Foucault)

A variedade dos discursos e dos jeitos de dizer o mundo, enunciados por cada personagem no documentário "Pro dia nascer feliz", constitui um painel ilustrativo dos múltiplos letramentos na escola brasileira e da variação linguística que liga o Brasil de Norte a Sul. Do extremo sertão nordestino à selva de pedra do sul do país, uma viagem pelos 


\section{S Linguagens}

corredores de escolas, principalmente públicas, evidencia a riqueza linguística nos discursos de cada aluno. Cada voz enunciada é um grito que legitima e fomenta a discussão acerca de um ensino que respeite a pluralidade linguística dentro da escola, conforme se discute neste estudo, a partir de entrelace entre discurso, variação e teoria de letramentos.

"Pro dia nascer feliz" é um documentário dirigido por João Jardim, que estreou no ano de 2007 e traz como temática principal a questão da realidade do ensino nas escolas brasileiras. Das carrocerias dos superlotados caminhões paus de arara no sertão nordestino aos perigos e violências dos morros das grandes favelas brasileiras, o diretor desvela a face de uma escola perdida na imensidão de tantas 'ondas' de violência e descaso público, evidenciados por meio de problemas como: más condições de acesso e permanência na escola; falta de estrutura física, pedagógica e de segurança; orçamento financeiro limitado para a manutenção da escola; má qualidade da merenda pública; alto índice de evasão e defasagem de alunos; professores com formações insuficientes para atender aos desafios da prática; círculo da violência, desrespeito e diversos tipos de preconceito: entre alunos, entre professores e entre professores e alunos, principalmente estes agredindo e ameaçando os docentes em sala de aula; desmotivação para o trabalho por parte dos professores; enfim, uma pluralidade de mazelas e transtornos que permeiam os extremos do mapa do país, e que denunciam a situação de descaso, abandono, desrespeito e negligência, principalmente por meio das políticas governamentais para com a educação, embora seja esta o maior 'trunfo' do qual se utilizam em seus discursos de campanha política.

Esse quadro é construído a partir da descrição de diferentes contextos sociais, econômicos, políticos e culturais, evidenciados pelo abismo entre realidades de escolas públicas e privadas. As cenas fílmicas baseiam-se todas em fatos reais, tomando como fonte de coleta de dados os depoimentos de diversos sujeitos da educação, que constituem a visão da instituição escola, do professor, do aluno e de suas famílias. Diante de tal realidade, a reflexão foucaultiana na epígrafe, sustenta o posicionamento de que é preciso preocupar-se com a realidade da educação brasileira.

É sobre esse contexto de conflitos e divergências culturais, políticas e ideológicas que se situa a discussão que se apresenta neste estudo, com o objetivo de analisar a realidade da educação brasileira retratada no documentário "Pro dia nascer feliz", a partir dos aspectos

Linguagens \& Cidadania, v. 19, número especial, jan./dez., 2017. 


\section{S Linguagens}

teóricos de discurso, variação e letramentos que constituem os modos de ver e dizer o mundo, pela ótica de cada personagem do documentário.

Para tanto, parte-se de uma abordagem qualitativa dos dados, oriundos de uma pesquisa bibliográfica, baseada principalmente na sociolinguística educacional desenvolvida por Bortoni-Ricardo (2004/2005), ao interessar-se pelo "estudo da língua e o estudo da sociedade" (2004, p. 10); além de: Antunes (2009), Bagno (1999), Cagliari (1999), Labov (1972/2008), Kleiman (1995), Marcuschi (2010), Signorini (1999), Street (1995), entre outros; bem como os Parâmetros Curriculares Nacionais da Língua Portuguesa (BRASIL, 1998), que contribuirão para o enriquecimento das análises fílmicas.

A escolha do documentário para corpus de análise deu-se em virtude de nele serem encontradas manifestações que revelam o papel da escola e de seus principais agentes, alunos e professores. Metodologicamente, junto à pesquisa bibliográfica, fez-se uma análise documental de algumas falas das personagens; elas revelam a relação entre a identidade do sujeito falante e o contexto social que interfere nas suas realizações linguísticas. Levando-se em consideração que o documentário foi construído a partir de depoimentos reais, há diversos fatores sociais que caracterizam os sujeitos, como os grupos etários, o gênero, o status socioeconômico, o grau de escolarização, entre outros, que influenciam na variação linguística, conforme a orientação da sociolinguística educacional, proposta por BortoniRicardo (2004/2005).

$\mathrm{Na}$ seleção das falas a serem transcritas, foram mantidas as marcas de oralidade, repetições e truncamentos, comuns à linguagem oral, respeitando, inclusive, as orientações da sociolinguística educacional, no sentido de legitimar usos não privilegiados da língua no espaço escolar. Essa opção de apresentação dos dados não comprometeu a fluidez e a clareza do texto e valorizou o sentido original, o 'dizer' de cada agente da educação, como se perceberá ao longo do texto, a seguir.

\section{DISCURSO, VARIAÇÃO E LETRAMENTOS: COMPREENDENDO AS TEORIAS}

O discurso pautado na aquisição de normas e técnicas sobre o que falar e o que escrever, e como dizer o mundo, tem sido referenciado pela escola ao longo do tempo, o que

Linguagens \& Cidadania, v. 19, número especial, jan./dez., 2017. 


\section{S Linguagens}

conduziu o ensino a uma segregação e discriminação secular a qual tem repercussão até os dias atuais. Entretanto é preciso salientar que a língua não é adquirida na escola, nas aulas de Língua Portuguesa ou mesmo no contato com professores, como bem apontam Labov; Harris (1986). Essa visão foi difundida porque a agência escola tem o perfil, muitas vezes de ditar, monitorar o vernáculo dos alunos para tornar o seu falar "culto", um discurso que mais se assemelha a um preconceito linguístico (BAGNO, 1999). O fato é que, “[...] a linguagem praticada na escola, por ser muito formal, é inacessível aos alunos provenientes de classes populares" (KLEIMAN, 1995, p. 121), o que demonstra a incompatibilidade do fazer pedagógico com as reais necessidades do aluno, não tendo como base seu contexto social, econômico e cultural.

É a partir daí, então, que as questões referentes ao letramento social e o esclarecimento sobre as variações linguísticas se fazem essenciais para a educação desses alunos. Kleiman (1995) enfatiza serem os alunos falantes bidialetais, por terem adquirido a linguagem informal no seio familiar e se apropriado da norma padrão da língua na escola. Contudo, a alternância na variação, principalmente por não privilegiar o padrão estabelecido como culto, faz com que a escola o marginalize. Além disso, fatores sociais influenciam a estigmatização no ambiente escolar, pois não se faz, muitas vezes, o diagnóstico da comunidade escolar e não se considera o conhecimento de mundo que eles já trazem consigo, desconstruindo suas verdades para inseri-los no mundo letrado, dentro de um padrão de comportamento normatizador, imposto pela escola.

Marcuschi (2010) afirma que até a década de 80, a noção que se tinha de língua estava baseada na análise de um sistema organizado e homogêneo, além de previsível, nos moldes do estruturalismo saussureano. A escrita, nessa abordagem, encontra supremacia, pois era através dela que o indivíduo se tornava civilizado e adquiria conhecimento. Dessa forma, a alfabetização é vista como a melhor maneira de se conquistar a aprendizagem, uma vez que é um método baseado na sistematização e no domínio da leitura e da escrita, por meio do ensino escolar. A ideia disseminada era que a partir da relação entre alfabetização e letramento, o indivíduo aprendia sua língua natural e se inseria na cultura, sendo assim aceito socialmente.

Contudo, a alfabetização centra-se apenas em uma abordagem da língua voltada para o código e não contempla as práticas sociais e os usos linguísticos. É assim que os estudos sobre letramentos ganham notoriedade, por considerar não só a escrita, mas as diversas 


\section{S Linguagens}

situações em que o indivíduo está imerso ao uso dessa prática nas mais variadas formas de comunicação em sociedade. Por isso, segundo Street (1995), hoje se fala em "práticas de letramentos" e não letramento, no singular, pois este remete à alfabetização escolar, de forma regular e institucionalizada. O autor diferencia aquisição da linguagem de "letramentos sociais", práticas essas que se estabelecem fora do âmbito escolar, nas atividades socioculturais também indispensáveis à formação do sujeito.

Por isso, é importante salientar, de acordo com Marcuschi (2010, p. 21-22) a diferenciação entre letramento, alfabetização e escolarização quando afirma que "letramento é um processo de aprendizagem social e histórica da leitura e da escrita em contextos informais e para usos utilitários", enquanto que a alfabetização "pode dar-se à margem da instituição escolar, mas é sempre um aprendizado mediante ensino, e compreende o domínio ativo e sistemático das habilidades de ler e escrever". Já a escolarização "é uma prática formal e institucional de ensino que visa a uma formação integral do indivíduo". Nessa abordagem, entende-se que a alfabetização é apenas um dos processos da escolarização, pois a escola tem outras atividades e projetos mais amplos, que fazem parte do letramento do aluno.

É preciso que se considere a variação sociocultural presente nos mecanismos linguísticos proferidos pelo aluno, levando em consideração sua cosmovisão e dificuldades encontradas para que o ensino não seja retrógrado, tendo como base apenas técnicas que servirão para medir sua competência gramatical, e não sua compreensão sobre o que se ler e escreve. Para isso, o discurso utilizado pelos educadores deve estar pautado no resgate dos saberes culturais da região, com a elaboração de trabalhos que façam parte da atividade laboral desempenhada nos locais onde os alunos vivem, aproveitando as práticas sociais para direcionar a metodologia pedagógica em sala de aula, conforme orienta os Parâmetros Curriculares Nacionais (BRASIL, 1998).

$\mathrm{O}$ respeito para com as diferenças na e sobre a língua são essenciais para que se chegue a uma escola que contemple as práticas sociais e os vários letramentos existentes. Assim, destaca-se a observação de Antunes (2009), ao tratar das diversas formas que a língua assume nas práticas sociais, a partir da inter-relação entre quatro realidades, que são: língua, cultura, identidade e povo, sendo a língua, portanto, um reflexo da historicidade de uma sociedade. Isso explica o uso variado da língua nas diferentes localidades regionais (variação diatópica), as desigualdades sociais (variação diastrática) e as faixas etárias e gêneros 


\section{S Linguagens}

diferentes (variação diafásica) nos quais os alunos estão inseridos, que estão relacionadas à utilização da variedade não-padrão e da norma culta da linguagem, segundo Bagno (1999).

Deste modo, a escola precisa reconhecer os múltiplos discursos que constituem a variação e os letramentos dos alunos, considerando e respeitando as distintas formas de falar e de dizer o mundo, explicitadas pelas manifestações linguísticas, porém, este ainda é um dos grandes desafios enfrentados no ensino de Língua Portuguesa, conforme se discute a seguir.

\section{EDUCAÇÃO BRASILEIRA: SOBRE O ENSINO DE LÍNGUA PORTUGUESA E A VARIAÇÃO LINGUÍSTICA NA ESCOLA}

Ao tratar da questão do ensino da Língua Portuguesa e dos aspectos de variação linguística que compõem os falares e letramentos na escola brasileira, é preciso antes pensar nas formas como esse ensino foi historicamente construído e organizado. Este projeto se deu a partir de uma cadeia vertical na relação professor-aluno, o que sacramentou uma cultura de ensino escolar tradicional, normativo e hierarquizador, que não oferecia clareza ou possibilidades para o aluno responder com eficiência as demandas sociais de domínio e expressão da língua, e tão pouco, respeitava a diversidade e pluralidade cultural da língua materna, os diferentes modos de dizer a mesma coisa e dizer o mundo, presentes nos discursos de cada aluno. E desse modo, estabeleceu padrões qualificadores e antagônicos: o "certo" e o "errado", e que permanecem até hoje, desconsiderando a variedade linguística e negando o valor existente nos falares considerados sem prestígio.

Essa situação desencadeou um dos principais desafios no ensino de Língua Portuguesa vivenciados atualmente: a necessidade de se reconhecer a variedade de fenômenos linguísticos e/ou linguageiros que compõem o espaço da sala de aula, uma vez que esta se constitui como um campo de disputas entre diferentes falares, que precisam ser respeitados e considerados, posto que "o aluno, ao entrar na escola, já sabe pelo menos uma dessas variedades - aquela que aprendeu pelo fato de estar inserido em uma comunidade de falantes" (BRASIL, 1998, p. 81), assim aponta os Parâmetros Curriculares Nacionais da Língua Portuguesa, ao reconhecer que:

Linguagens \& Cidadania, v. 19, número especial, jan./dez., 2017. 
A variação é constitutiva das línguas humanas, ocorrendo em todos os níveis. Ela sempre existiu e sempre existirá, independente de qualquer ação normativa. Assim, quando se fala em "Língua Portuguesa" está se falando de uma unidade que os constitui de muitas variedades. Embora no Brasil haja relativa unidade linguística e apenas uma língua nacional, notam-se diferenças de pronúncia, de emprego de palavras, de morfologia e de construções sintáticas, as quais não somente identificam os falantes de comunidades linguísticas em diferentes regiões, como ainda se multiplicam em uma mesma comunidade de fala (BRASIL, 1998, p. 29).

A escola precisa compreender a língua como muito mais do que um instrumento de comunicação, mas como ferramenta de interação, que possibilita a inserção social e cultural do indivíduo no mundo, de modo que não há um 'certo' ou um 'errado', mas um conjunto de elementos particulares que asseguram a comunicação e interação social entre os sujeitos. Pensar a língua nessa dimensão é, portanto, compreendê-la como prática social, ao mesmo tempo, de homogeneidade e heterogeneidade, uma vez que ela é uma faculdade coletiva de interação humana. Ela comporta particularidades relativas à construção de uma identidade e delimita um espaço de ação social, definido a partir do 'jeito' de enunciar de cada aluno em processo de aprendizagem formal da língua materna.

Signorini (1998, p. 141) ao analisar situações comunicativas em esferas públicas, onde ficam evidentes as variações e as identidades sociais dos sujeitos, reflete que é preciso pensar na "relação de causa e efeito estabelecida entre letramento escolarizado e racionalidade na produção do discurso, entre modos letrados escolarizados de exposição oral e competência comunicativa", ou seja, a sociedade espera da escola a responsabilidade de formar o aluno dentro de padrões linguisticamente 'corretos', e desse modo, a instituição é levada a desconsiderar e desrespeitar sua identidade linguística.

Ao estudar os fenômenos de variação linguística, o sociolinguista William Labov (1972), embora sem interesse direto no ensino, na questão da norma dialetal ou nas questões educacionais, mas tratando apenas de "identificar as razões e os fatores que contribuem para a variação e pouco lhe interessa qual a variedade a ser adotada no ensino", como destaca Marcuschi (2010, p. 32), buscou, a partir de um estudo de caso de base empírica, realizado em contextos não escolares, entender o fenômeno da mudança linguística, a luz de três problemas distintos: "a origem das variações linguísticas, a difusão e propagação das mudanças linguísticas; e a regularidade da mudança linguística" (LABOV, 2008, p. 19). Ao observar as condições de fala e produção de enunciados de informantes, percebeu que a língua muda, 


\section{S Linguagens}

transforma-se, varia e está relacionada à construção da identidade do indivíduo e ao lugar social de onde está, e que esta variação decorre de fatores, como etnia, classe social e econômica, nível de escolaridade, sexo, entre outros, bem como fatores de ordem geográfica e sócio-histórica, que interferem nas realizações de falas.

Trazendo a discussão à realidade da escola brasileira atual, Ferrarezi Jr. (2014, p. 11) aponta que "nossas escolas são estranhamente silenciosas" e que essa crise do silenciamento se reflete diretamente no ensino da língua materna, evidenciada principalmente, na forma como os professores que foram educados no século passado buscam educar seus alunos dentro dos mesmos moldes. Porém, é preciso considerar os adventos contemporâneos, os impactos socioculturais oriundos das transformações do século XXI, que afetam diretamente os modos de aprender e de ensinar, sobre estes principalmente, uma vez que não se tem mais um aluno passivo diante do conhecimento do professor. A linguagem do aluno de hoje é múltipla, plural e dinâmica, marcada pela variação e pela diversidade nos modos de enunciar suas visões sobre o mundo. Desse modo, metodologias de ensino ultrapassadas não respondem a contento aos desafios dessa nova realidade.

Ao preocupar-se com questões educacionais, Bortoni-Ricardo (2005) propõe uma sociolinguística educacional centrada nas práticas de linguagem utilizadas em sala de aula, ressaltando a importância de considerá-la “como um espaço sociolinguístico multidimensional, no qual professores, alunos e demais profissionais do ensino estão permanentemente submetidos a múltiplas influências determinantes de um comportamento linguístico muito variado" (p. 183). Assim, é preciso reconhecer e considerar as estruturas culturais subjacentes ao espaço físico da escola, promovendo, ao mesmo tempo, o ensino dos estilos formais da língua padrão e o respeito à pluralidade de falares dos alunos.

Essa conscientização, parte do fato de que, do ponto de vista da sociolinguística educacional, "a noção de "erro" nada tem de lingüística - é um (pseudo) conceito estritamente sociocultural, decorrente de critérios de avaliação (isto é, dos preconceitos) que os cidadãos pertencentes à minoria privilegiada lançam sobre todas as outras classes sociais" (BORTONIRICARDO, 2004, p. 08). Ao valerem-se desse discurso preconceituoso com as formas de uso da língua, os defensores de uma 'língua pura', lutam em prol da manutenção de um estatuto hierárquico da língua, no tratamento social que lhe é atribuído, através de estratificações, que

Linguagens \& Cidadania, v. 19, número especial, jan./dez., 2017. 


\section{S Linguagens}

segregam e criam redes de tensões e negligenciamentos da condição humana, baseando-se nos radicais conceitos de "certo" e "errado".

A manutenção desse status, que privilegia o "certo", fruto de uma visão autônoma, estritamente burocrática e bancária, vai, de modo desvelado, construindo sólidos baldrames de sustentação dos muros que cercam e dominam o preconceito linguístico, resguardando para poucos - considerados membros de uma considerada elite intelectual e financeira -, os usos privilegiados da língua, em contraposição aos 'maus usos', 'impuros', relegados ao campo do menosprezo social. Em combate a essa postura, Cyranka (2011, p. 144), baseando-se na proposta defendida por Bortoni-Ricardo (2004/2005), destaca que:

\footnotetext{
A Sociolinguística, considerando a contraparte social da linguagem, oferece o caminho para o tratamento adequado da heterogeneidade linguística na escola. Para essa ciência, a variação e a mudança linguísticas são processos naturais e têm motivações várias, entre elas, a identidade dos falantes dentro de seu grupo social e até mesmo de localidade geográfica.
}

A proposta então, aponta para um ensino que valorize os letramentos dos alunos, reconhecendo e ampliando-os, aliando, desse modo, o letramento em sentido estrito: o acadêmico promovido pela escola; e no sentido lato: o conhecimento cultural e usos da escrita na sociedade (BORTONI-RICARDO, 2005). Dessa articulação resulta uma sintonia entre os discursos próprios dos alunos e a proposta curricular da escola.

A proporção dessa problemática é visualizada no documentário "Pro dia nascer feliz", o qual se analisa a seguir, considerando a escola como um espaço de reconhecimento da natureza plural dos falares do brasileiro e seus múltiplos discursos e letramentos que constituem a grandeza da língua materna nacional.

\section{OS BRASIS EM “PRO DIA NASCER FELIZ": PERPSECTIVAS ANALÍTICAS}

O mote inicial da história é a apresentação de dados da educação brasileira sobre leitura e escrita, que constituem um "panorama sombrio", conforme anuncia o locutor: "1962 - De quatorze milhões de brasileiros em idade escolar, apenas a metade chega a frequentar aulas e aprender a ler".

Linguagens \& Cidadania, v. 19, número especial, jan./dez., 2017. 


\section{Linguagens \& Cidadania}

Dito isto, o letreiro branco sobreposto em uma tela preta, aludindo a uma situação de luto por esta realidade, apresenta-se ao expectador:

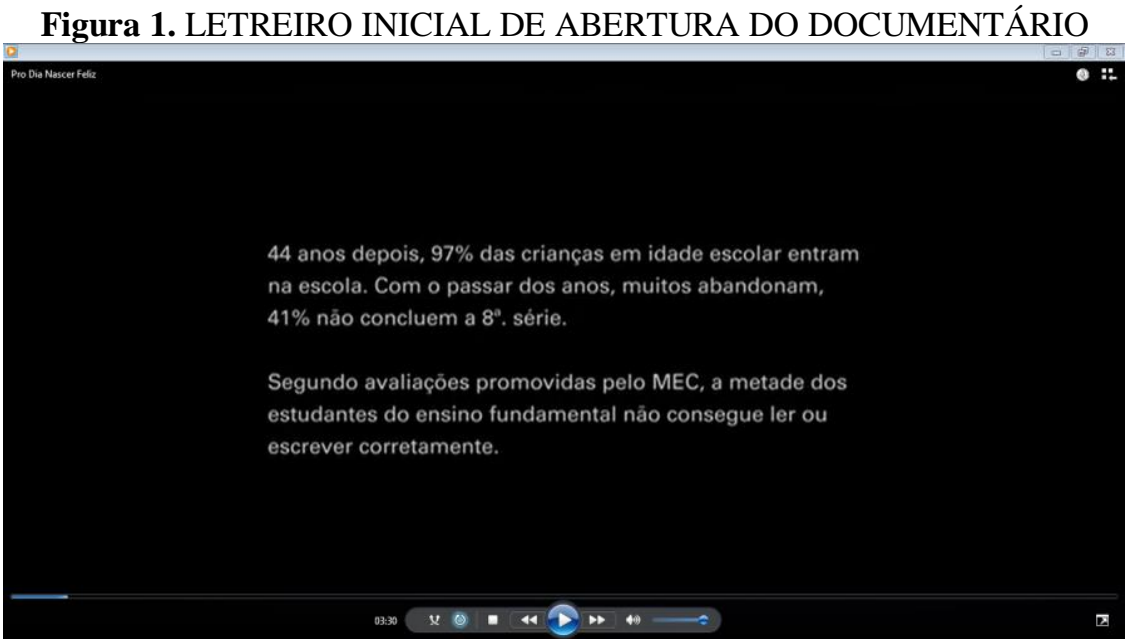

Fonte: Documentário "Pro dia nascer feliz" (2006)

Contrariando essa imagem, toma cena um imenso vazio representando o sertão nordestino, de onde ecoam os versos do poema "Ausência", de Vinícius de Moraes, na voz de uma jovem estudante de Manari, Pernambuco, definida como "uma das cidades mais pobres do Brasil", ponto inicial de onde surgem as histórias que compõem o enredo do documentário. O ano é 2004. Encontram-se em cena as realidades de escolas de três estados brasileiros: Pernambuco, Rio de Janeiro e São Paulo, os quais mostram, de forma peculiar, a variedade de discursos e letramentos dos alunos, advindos de cada região.

O deslocamento das cenas se dá entre as seguintes escolas: "Escola Estadual Cel. Souza Neto - Manari, Pernambuco"; "Escola Estadual Dias Lima - Cidade de Inajá, Pernambuco"; "Colégio Estadual Guadalajara - Duque de Caxias, Rio de Janeiro"; "Escola Estadual Parque Piratininga II - Itaquaquecetuba, São Paulo"; "Colégio Santa Cruz - São Paulo"; "Escola Estadual Levi Carneiro - periferia de São Paulo"; e outra instituição, definida como: "Em Outra Escola". Essas diferentes realidades constituem o painel do cotidiano educacional da escola pública e privada brasileira, mostrando principalmente a pobreza e a falta de recursos em duas escolas públicas da região nordeste, no estado de Pernambuco; a precariedade e violência de uma escola pública na favela do Rio de Janeiro; as situações de barbárie em uma escola pública de uma cidade paulista; uma escola pública em boas

Linguagens \& Cidadania, v. 19, número especial, jan./dez., 2017. 


\section{Singuagens}

condições de ensino também em São Paulo; e uma tradicional escola católica da rede privada de ensino, na capital paulista.

O foco principal do documentário são as relações do adolescente com a escola, permeadas por questões que constroem muros de segregação e abismos sociais, demarcados por fatores de ordem econômica, política e cultural, como desigualdades, violência (física e simbólica), entre outras; que apresentam a escola como palco de conflitos e contradições, as quais estão imbricadas em aspectos referentes à linguagem e nos modos de dizer de cada sujeito, evidenciados por falares advindos de um lugar social de onde enunciam.

Esses problemas são desvelados nas falas dos sujeitos da história, que utilizam de diferentes termos ou expressões para dizer, muitas vezes, as mesmas situações que vivenciam, evidenciando assim, que "todas as variedades, do ponto de vista estrutural linguístico, são perfeitas e completas entre si. O que as diferencia são os valores sociais que seus membros têm na sociedade" (CAGLIARI, 1999, p. 22), ou seja, a forma como o aluno do sertão nordestino vai referir-se aos problemas educacionais e aos conflitos que vivencia difere das formas do aluno do sul do país, ao expressar seus dilemas, ficando claro, assim, os modos culturais e os níveis de letramentos de cada sujeito.

Os discursos sobre os problemas da educação podem ser identificados nas críticas à instituição escola, principalmente pelas falas ${ }^{1}$ dos protagonistas do processo: professores e alunos. Estes últimos tecem argumentos sobre o panorama da educação no Brasil, a partir dos problemas que vivenciam em suas realidades, apontando para fatores negativos, os quais se tornam presentes, justificando, assim, o porquê do déficit no sistema, como pode ser visto neste trecho:

Não só o governo, mas a escola em si passa uma imagem que o ensino tá melhorando, tá melhorando, tá melhorando, mas não tá! Se tivesse melhorando a gente não precisava desse programa do PRO Universitário, você num precisava de cotas de universidades, se tivesse melhorando você não precisava fazer isso (CRÍTICA DE UM ALUNO À ESCOLA BRASILEIRA, Min. 38').

\footnotetext{
1 Uma vez que o trabalho analisa as variáveis culturais expressas nas falas dos personagens do filme, as transcrições foram feitas, mantendo-se as marcas expressivas, comuns à linguagem oral e a preocupação em zelar pelo sentido original do que foi dito. Esse fato não impediu a fluidez e a clareza do texto.
}

Linguagens \& Cidadania, v. 19, número especial, jan./dez., 2017. 


\section{Singuagens}

No fragmento fílmico, é possível traçar um perfil imagético do aluno de escola pública com base no discurso idealizado por este acerca da educação e da escola, enquanto agência reprodutora de nivelamentos sociais. Percebe-se um falante brasileiro que enuncia a partir de uma realidade social desfavorecida, especificamente a região de Itaquaquecetuba, a 50 quilômetros da cidade de São Paulo. A maioria das pessoas que vive no local foi estigmatizada secularmente ao longo do processo educacional, uma vez que pela fala do sujeito, fica claro a não melhoria na educação ao longo do tempo, mesmo com a aplicação de projetos do Governo Federal, como o PRO universitário ${ }^{2}$ e o sistema de $\operatorname{cotas}^{3}$, sejam raciais e/ou sociais, o que se pode ver nas marcas de uma cultura predominantemente oral, ao afirmar que parece que "o ensino tá melhorando, tá melhorando, tá melhorando, mas não tá!", ou seja, há apenas um discurso sobre a questão, no entanto, na prática, não é efetivado. Essa ausência na melhoria da educação reflete os milhões de analfabetos funcionais, o pouco estímulo à leitura, além de intensificar a falta de interesse dos alunos. Tudo isso gera indisciplina e reforça a importância do debate sobre a ação pedagógica no Brasil, além de um olhar mais atento do Estado para a questão.

O fracasso apontado neste discurso é referente, muitas vezes, à má gestão dos recursos orçamentais direcionados à educação, que não atende as necessidades de 210 mil escolas no Brasil (Censo Escolar 2004/MEC - INEP); além da falta de financiamento do governo, visto que o documentário destaca que cerca de 13,7 mil escolas não tinham banheiro e 1,9 mil não tinha água (MEC, 2004). Críticas como essas são ressaltadas em discursos como esses abaixo:

Veja só, vocês sabe que o dinheiro que vem pra escola já é muito. Aí vem 1200 reais.... Eita se fosse por mês era bom demais! (Risos) 200 reais já é separado, esse aqui é do INSS... Diz logo aqui, olha. Agora, apareceu mais outro NSS num sei de quê. É mais $11 \%$, aí já vai mais 110 reais. 50 reais é da prefeitura e a prefeitura nem pode perdoar. Nós temos que pagar o contador, aí veja só, quando a gente vai ficar no final vai ficar com 600 e poucos reais. (CRÍTICA DE UM FUNCIONÁRIO DE UMA ESCOLA PÚBLICA, Min. 5' 07',)

\footnotetext{
2 O Programa Pró-Universitário visa estimular o aumento de alunos da Rede Estadual entre inscritos e ingressantes no ensino público superior. Constitui-se também, de um programa voltado para pessoas que se interessam em fazer um curso superior, mas não têm condições financeiras.

${ }^{3}$ No Brasil, existe desde os anos 2000 e foi criado para dar acesso a negros, índios, deficientes, estudantes de escola pública e de baixa renda em universidades, concursos públicos e mercado de trabalho.
}

Linguagens \& Cidadania, v. 19, número especial, jan./dez., 2017. 
Os banheiros, assim, não tem descargamento e também não têm pia de lavar as mãos, não tem papel higiênio. [...] na escola, como vocês verem aqui, olha a situação das parede, do mato na escola! (POSICIONAMENTO DE UMA ALUNA SOBRE A ESTRUTURA DA ESCOLA, Min. 7' 27'’)

Nota-se pelas falas que há uma diferença entre a cultura da oralidade e a cultura essencialmente da escrita, conhecida por cultura de letramento (BORTONI-RICARDO, 2004). A primeira pode ser observada pelas variações linguísticas que representam uma transição e mudança entre o domínio utilizado em sala de aula e no meio social, utilizado em outros contextos, como em uma entrevista no pátio da escola, por exemplo, que permite a construção de um conversa informal, ou seja, menos monitorada, como em expressões, como: "Veja só, vocês sabe"; "Agora, apareceu mais outro NSS num sei de quê"; "aí veja só"; "Os banheiros, assim, não têm descargamento"; "não tem papel higiênio"; "olha a situação das parede"; em que os falantes se apropriam da língua e dos traços variacionistas - como a ausência do plural em "vocês sabe" e em "situação das parede"; as expressões que tentam intermediar a relação interpessoal por meio de mecanismos que chamam a atenção do interlocutor, como em "aí veja só"; e o neologismo, com a palavra "descargamento" - os quais revelam a comunidade linguística de onde pertencem, mostrando que há uma relação indissociável entre língua e sociedade.

Além disso, a verba pública direcionada para manter a instituição é ínfima, o que traz prejuízos para o investimento em projetos culturais e sociais desempenhados pela escola ao longo dos anos, prática essa que norteia o trabalho do professor em sala de aula - como, por exemplo, esclarecimentos sobre a linguagem voltada às ideias da sociolinguística -, além de ser uma exigência do programa o resgate ao interesse do alunado por assuntos programáticos da escola, bem como por ações sociais, fazendo-o um ser ativo no processo de ensino e aprendizagem. Outrossim, é possível inferir na fala acima que o dinheiro repassado mal paga as despesas, o que acaba lesando o funcionamento da escola.

Nesse quadro lamentável destaca-se também, a falta de incentivo à qualificação de profissionais inseridos nesse contexto educacional, e o principal, o pouco assistencialismo do governo para com os estudantes. Em contrapartida, há um desinteresse dos próprios professores como protagonistas desse processo educacional, visto que, muitas vezes, pela desvalorização dada à categoria, tornam-se profissionais descomprometidos com a função de educar, o que pode ser visualizado no fragmento que segue:

Linguagens \& Cidadania, v. 19, número especial, jan./dez., 2017. 
Mas tem professor que num vai nem na sala. A exemplo disso tem um professor de química que ele nunca vai na nossa sala, só manda uma substituta. Então eles acham que a gente já num sofre daqui pra lá e quando chega lá num tem lucro nenhum. (CRÍTICA DE UM ALUNO EM RELAÇÃO À POSTURA DE UM PROFESSOR DE UMA ESCOLA PÚBLICA, Min. 14 ' 36')

Com a gente aconteceu ano passado com a professora de Sociologia. Até os desistentes, assim, tinha as mesma nota que a gente que assistia aula dela todos os dias. Como ela num ia pra sala num sabia distinguir quem tava estudando mais, quem num tava, quem já tinha ido embora, quem já tinha fugido. Todo mundo era a mesma nota, digamos, se a média era oito era todo mundo oito. (CRÍTICA DE UM ALUNO EM RELAÇÃO À POSTURA DE UM PROFESSOR DE UMA ESCOLA PÚBLICA, Min. 14' 53'’)

Pelas falas, nota-se o reconhecimento do papel social desempenhado pelos alunos, os quais têm consciência que possuem uma gama de direitos e deveres que lhes permitem o quê, quando e porquê dizer, dependendo do domínio social de onde enunciam. Dessa forma, os discursos dos estudantes revelam traços marcantes de variações da língua, que demonstram pertencer a um contexto social estigmatizado, no caso, o sertão pernambucano, na cidade de Manari, revelando estratégias discursivas próprias dos falares de tal região, como se pode ver na seguinte seleção lexical: "Mas tem professor que num vai nem na sala"; "Então eles acham que a gente já num sofre daqui pra lá e quando chega lá num tem lucro nenhum"; "Como ela num ia pra sala num sabia distinguir quem tava estudando mais, quem num tava"; em que o "não" é representado pela forma "num", típico traço de oralidade; o fenômeno da dupla negação, como em "num tem lucro nenhum"; além das palavras que possuem o mesmo significado, mas que mudam de região para região (variação diatópica), como a expressão mercadológica "lucro" para se referir a algo que se ganha.

Ademais, nesse contexto em que se tem o compromisso, através da sociolinguística educacional, de relacionar língua à sociedade como um "instrumento de luta contra toda forma de discriminação e de exclusão social pela linguagem" (BORTONI-RICARDO, 2004, p. 10), deve-se analisar também a realidade em questão, onde se revela o descaso que existe nas escolas brasileiras quanto à falta de direcionamento e de autonomia do professor para guiar o aluno, o que não é recomendável que aconteça, pois o fio condutor do ensino e aprendizagem é a abordagem pedagógica, a didática do docente enquanto auxiliar do desenvolvimento intelectual do aluno. Se o docente resolve 'fechar os olhos' para uma função que lhe compete executar, as consequências desse ato podem acabar vitimando os alunos de 


\title{
S Linguagens
}

uma forma irreversível. Em contrapartida, sabe-se que a postura do professor depende também, de como este é visto pelo sistema, pois se ele é valorizado poderá desenvolver práticas educacionais mais significativas, voltadas para a inserção do alunado na sociedade, tornando-o um cidadão, mas se ele for estigmatizado pode provocar déficits para a educação brasileira.

Para tentar se eximir dessa tarefa, muitos professores culpam os próprios alunos pela ineficácia no processo educacional, revelando o desinteresse destes pelas aulas, a falta de desempenho na resolução de atividades, o que provoca a evasão escolar ao longo do ano letivo. O discurso abaixo corrobora para essa constatação:

\begin{abstract}
Eu acho que eles vêm assim como se fosse pra extravasar, não todos. Alguns vêm mesmo pra aparecer, pra se mostrar. Eu digo mesmo as meninas, elas vêm, se arrumam, vêm como quem vão para um baile, ficam nos corredores paquerando. Muitas nem entram. Umas entram, botam o caderno e voltam. Eu já conheço todas e digo assim 'Cadê fulana?' 'Ah, ela tá lá na rua namorando'. Quer dizer, elas veem como um escape. O pouco que se tem é essa aula mesmo e assim mesmo eles num querem! Então, a gente se desestimula! Eu era das professora que ficava aqui até o último horário, sabe? 10h eu ficava aqui. Aí eu vejo os outros todos desinteressados por causa dos alunos mesmo, aí vai embora. Tá, nove e pouco vamos embora! E eles ficam mesmo 'Vamo embora, vamo embora!'. E hoje num tem, hoje faltam 11 professores aqui que vão para uma pós-graduação, então dia de sexta é furado aqui. Se eles não mandarem substituto, já fica furado... (CRÍTICA DE UMA PROFESSORA SOBRE A POSTURA DOS ALUNOS EM UMA ESCOLA PÚBLICA, Min. 15' 25’')
\end{abstract}

Observa-se na fala da professora do Estado de Pernambuco que as variações linguísticas expressas no discurso quase nada se diferenciam das dos alunos da mesma escola outrora analisados, no que diz respeito ao monitoramento, a espontaneidade do dizer. Expressões como "eles vêm assim como se fosse pra extravasar"; "'Cadê fulana?"”; "Ah, ela tá lá na rua namorando"; "O pouco que se tem é essa aula mesmo e assim mesmo eles num querem!"; "Eu era das professora que ficava aqui até o último horário, sabe?”; "Tá, nove e pouco vamos embora!"; "Vamo embora, vamo embora!"; "E hoje num tem"; "dia de sexta é furado", revelam um linguajar que nada pode ser comparado ao "erro" - por se distanciar das normas da gramática tradicional -, e não é porque se trata de um recurso linguístico realizado por um professor, em um depoimento sobre como funciona a educação nesta escola, pois mesmo que fosse de um aluno, ou qualquer membro composicional da escola ou de qualquer outro domínio social, 


\section{Singuagens}

[...] estamos diante de diferenças e não de "erros". A noção de "erro" nada tem de linguística - é um (pseudo) conceito estritamente sociocultural, decorrente dos critérios de avaliação (isto é, dos preconceitos) que os cidadãos pertencentes à minoria privilegiada lançam sobre todas as outras classes sociais. Do ponto de vista estritamente linguístico, o erro não existe, o que existe são formas diferentes de usar os recursos potencialmente presentes na própria língua (BORTONI-RICARDO, 2004, p. 08) (Grifos da autora).

Já no que diz respeito à realidade sociocultural da educação no Brasil, constata-se na fala da professora que o sistema condicionou o educador a um descompromisso para com o aluno, uma vez que o docente "abandona" a sala de aula para realizar uma qualificação profissional. Isso, porém, acontece de forma errônea, já que ele utiliza os horários que deveria ser de cumprimento de sua função em sala de aula para realizar uma atividade que poderia ser realizada no contraturno ou em dias que não estivesse realizando seu trabalho, embora se reconheça a necessidade de investimento na formação docente continuada.

Nesse panorama ilustrativo da realidade da escola brasileira, o trabalho do professor é pautado em desafios e dificuldades as quais se diferenciam de acordo com o contexto socioideológico onde a instituição escolar se encontra, seja ela escola pública, como a do sertão pernambucano - em que os maiores empecilhos são a ausência da verba pública em transportes escolares para conduzir os alunos até à escola, falta de investimentos na estrutura escolar, ou mesmo a desvalorização do docente, como já foi destacado - ; ou mesmo na instituição privada em que os dilemas divagam entre as dúvidas existenciais dos alunos, como por exemplo, a escolha da profissão.

Entretanto, deve-se trazer para a discussão desses desafios, as estratégias para auxiliar o professor em uma tarefa muitas vezes complexa, que é a de estar preparado, não só em termos de conteúdo para levar informações aos alunos - de modo que também respeitem as variedades linguísticas existentes no âmbito escolar -, mas também psicologicamente, sobretudo quando se trata da realidade de escolas públicas, como as da região paulista, onde os educandos encontram-se inseridos em um contexto de violência e de desestruturação familiar, levando essa problemática para o ambiente escolar, o que acaba, de certa forma, refletindo no seu vocabulário e nos seus modos de fala. $\mathrm{O}$ discurso de uma professora revela algumas dificuldades enfrentadas no desenvolvimento de sua prática, expressas por um registro que mostra a estreita relação entre língua e sociedade:

Linguagens \& Cidadania, v. 19, número especial, jan./dez., 2017. 
Olha, eu falto, por quê? Por cansaço. Eu acho que ser professor e tá envolvido mesmo com a profissão, com eles, com os alunos e tal é uma carga física e mental muito grande... é mais do que um ser humano pode suportar. Porque é muito psicológico, sabe? É... eu faço terapia uma vez por mês, eu tenho que ir no psiquiatra porque num dá, porque você se envolve nos problemas deles e nem sempre você tem o retorno. Às vezes você entra numa sala de aula e você é mal recebido, porque o professor ainda é visto pela maioria dos alunos como o inimigo, né? Então, existe um abismo muito grande ainda entre professor e aluno, professor e diretor. A impressão que eu tenho é que ninguém se entende, né? A falta acontece por isso. Às vezes é... poxa vida, você tá lá, você estudou e tal, você entra numa sala de aula e o cara manda você tomar naquele lugar etc. Então, é complicado lidar com essa situação. Sabe, o papel do professor na sociedade ele é muito importante, só que ninguém dá essa importância. Então, quando você abandona o profissional ele tende a que? A deixar pra lá... sabe? Eu acho que o professor perdeu a dignidade, na verdade a gente não tem dignidade pra trabalhar. Você tem que aceitar muitas coisas dentro da sala de aula e isso vai deixando você com o espírito cada vez mais pobre. O Estado deixa tudo muito jogado, sabe? Num tem ninguém ali pra falar 'olha, mas você tá dando essa aula e tal, como é que tá sendo?' Maquia-se muito as coisas. Então, de repente 'ah, num vou dar nota vermelha por quê? Porque eu vou ter que fazer um documento falando porque que eu dei a nota vermelha pro indivíduo'. Então, pra não ter esse trabalho 'ah, põe uma nota azul lá, passa logo o infeliz!' Tá todo mundo cansado de ouvir quais são os problemas da educação, mas ninguém faz nada (CRÍTICA DE UMA PROFESSORA SOBRE A POSTURA DOS ALUNOS EM UMA ESCOLA PÚBLICA, Min. 39' 23' ').

O discurso mencionado acima revela as diferenças dialetais no léxico entre os falares da região nordeste (como observado anteriormente na fala de outra professora) e os da região sudeste, o que pode ser visto pela intensidade do uso da expressão "você", mas não para se referir ao interlocutor como um pronome de tratamento que é, mas para identificar o próprio "eu" do discurso, que é aquele que fala, no caso, a professora ao relatar suas inquietações no campo educacional, ou mesmo qualquer sujeito que se colocar no lugar de agente do processo, situação essa que pode ser visualizada nos fragmentos seguintes; "porque você se envolve nos problemas deles e nem sempre você tem o retorno. Às vezes você entra numa sala de aula e você é mal recebido"; "Às vezes é... poxa vida, você tá lá, você estudou e tal, você entra numa sala de aula e o cara manda você tomar naquele lugar etc."; "Então, quando você abandona o profissional"; "Você tem que aceitar muitas coisas dentro da sala de aula e isso vai deixando você com o espírito cada vez mais pobre"; "falar 'olha, mas você tá dando essa aula e tal, como é que tá sendo?".

No discurso, também se evidencia a burocracia autoexplicativa do Estado na decisão do professor em 'castigar' o aluno com uma nota vermelha, pois, neste caso, o docente é 


\section{S Linguagens}

levado a realizar um esclarecimento por meio de uma documentação que acaba por induzi-lo a não dar a devida nota ao aluno, tendo, assim, que passar o "infeliz" de um ano para o outro, mesmo sem este ter adquirido habilidades para isso. Dessa forma, a professora elucida um panorama desastroso da educação do Brasil, que vitimiza não só o educando nessa tomada de decisão errônea, mas também o professor, uma vez que este se encontra, muitas vezes, sozinho na execução de um trabalho que deveria ser realizado em parceria, em equipe.

Outra abordagem destacada no documentário é a forma como a escola particular conduz o ensino, muitas vezes baseado em imposições conteudistas e comportamentais que os alunos devem seguir, pois a postura da escola neste contexto é de agência reguladora de costumes que devem ser seguidos pelas pessoas, de um modo geral. Dessa forma, a escola particular se diferencia da pública, pois enquanto esta se mostra muitas vezes ausente em tentar resolver problemas simples, como colocar papel higiênico no banheiro ou mesmo dá suporte ao professor para que possa desempenhar seu trabalho de modo satisfatório, a particular traz outras questões que também merecem ser comentadas: uma delas é a pressão psicológica no padrão de excelência que os alunos devem ter, como se pode observar neste fragmento abaixo:

Eu fui falar com a direção, e sei lá... Os duzentos alunos que tão de recuperação, tendeu? E tão sofrendo. Tem muita gente querendo sair do colégio, eles chegaram e falaram 'não, isso é normal!' Entendeu? Então, eles querem mesmo apertar, querem mesmo fazê a gente vê o perigo! (ALUNA SOBRE A POSTURA DA ESCOLA PARTICULAR ONDE ESTUDA, Min. 57' 04'’).

$\mathrm{Na}$ fala da estudante observa-se o uso de dialetos típicos da geração da qual a aluna faz parte: adolescência. Seleções lexicais como: "Os duzentos alunos que tão de recuperação, tendeu? E tão sofrendo"; "eles querem mesmo apertar, querem mesmo fazê a gente vê o perigo!" dão certa fluidez ao discurso da jovem e são compreendidas, sem a necessidade de mais explicações, assim como em: "Eu fui falar com a direção, e sei lá..."; "Os duzentos alunos que tão de recuperação, tendeu?"; "eles chegaram e falaram 'não, isso é normal!' Entendeu?". Essas marcas são conhecidas como dialetos intergeracionais, pertencentes às diferenças mais marcantes entre as variações (BORTONI-RICARDO, 2004).

Quanto ao quadro representacional da problemática que a educação assume nesse contexto, observa-se que os dilemas vivenciados por alunos em redes particulares e na rede 


\section{S Linguagens}

pública são divergentes em vários aspectos, desde o abandono do professor em relação ao aluno, o abandono da escola frente à realidade do professor, como nos casos das escolas públicas nas regiões visitadas por João Jardim; até o contexto socioideológico privilegiado da escola particular, em São Paulo, por exemplo, onde os alunos sofrem não com a escassez ou mal uso da merenda pelos próprios alunos, mas com conflitos existenciais e pressões internas, respectivamente, como visto nos depoimentos a seguir, retirados de uma entrevista que as alunas participam nas gravações do documentário:

Eu tenho medo de coisas assim totalmente complexas e grandiosas, assim... que é medo da morte, medo do que vai acontecer depois, então, eu começo a pensar nisso e fico naquela noia e tem bilhões de perguntas na minha cabeça que eu sei que ninguém vai conseguir me responder...

[Entrevistador pergunta]: que tipo de perguntas?

Ah... o que que acontece depois da vida, quem sou eu, o que que vai acontecer comigo... pergunta, meu, sobre o tempo, como que tudo começou... coisas assim que.. cê começa a pensar nessa idade e que num tem resposta. Eu sou uma pessoa que... acho que com a graça de Deus... é... eu tive a ideia de conversar muito com as pessoas, então, quando começou a me dá essa depressão e esse meu problema eu fui direto falar com minha mãe, o diretor do colégio chamou pra conversar comigo $e$ minhas amigas foram pessoas que me ajudaram, só que de todas essas pessoas com quem eu falei ninguém me deu as respostas que eu queria. (DEPOIMENTO DE UMA ALUNA DA ESCOLA PARTICULAR, 58'18'’).

Por exemplo, agora tão ligando lá em casa porque um colégio... é... grande, uma rede... um colégio que tem uma rede de escolas bem grande tá ligando lá em casa falando com a minha mãe porque querem que eu vá lá com meu boletim... querem que eu estude lá o ano que vem...querem que eu faça cursinho lá... querem que... que... saia o meu nominho no cartaz se eu entrar na faculdade, porque eles me treinaram né... e... inclusive eu faço as Olimpíadas de Física... tal... e.... preparação.... e minha mãe já foi falando com a professora e eu nem tava querendo muito....e dai entra nisso... é... calmaí... eu to feliz aqui.... e eu acho que o importante da vida não é só isso. Eu quero tá livre pra... se eu num quiser mais saber de estudar... eu não ter que estudar.

[Entrevistador pergunta]: Que tipo de pressão você sofre assim do seu pai e da sua mãe?

A pressão é minha... minha! Eu me cobro muito, né. Meus pais num... meus pais até falam... chega! Não precisa mais estudar. Para com isso! (DEPOIMENTO DE UMA ALUNA DA ESCOLA PARTICULAR, 1' 04'’18',').

Ainda quanto à realidade da escola pública, no tocante à precariedade e mau uso da merenda escolar, como destacado anteriormente, tem-se a realidade de uma escola pública do sertão pernambucano, quando uma aluna fala que: "Quando é merenda, eles (os alunos) pegam as merenda joga nas sala, joga nas parede, joga na terra, diz que a merenda é pode, num quer...Eu mesmo acho que eles tão desvalorizando eles" (Min. 7'27''), o que reflete um Linguagens \& Cidadania, v. 19, número especial, jan./dez., 2017. 


\section{S Linguagens}

comportamento que destoa do esperado, considerando-se que a escola está situada em uma região carente de recursos financeiros, alimentícios e até sentimentais, onde "na maioria das vezes, num tem nem chance de sonhar" (ALUNA VALÉRIA SOBRE SEU CONTEXTO SOCIAL, Min. 9' 57'’).

Resistindo às dificuldades desse cenário, com a palavra, Valeria: aluna da Escola Estadual Cel. Souza Neto, que ocupa a cena final do documentário declamando um texto de autoria própria, na qual faz uma paródia do poema "Canção do Exílio", de Gonçalves Dias. O poema é resultado de uma atividade de Língua Portuguesa realizada em sala de aula, em que a professora ao trabalhar com a questão da intertextualidade propôs que ela imaginasse "uma situação onde vocês estivessem fora de Manari e fizessem comalá”. As palavras da aluna por si só dizem e representam a situação de 'exílio' e descaso em que vivem muitos alunos que compõem a grande sala de aula que é o Brasil, uma escola marcada por variação e letramentos múltiplos, enunciados em cada discurso de alunos ou professores, que em tom de crítica ou conformismo, é na verdade, uma alerta e um pedido de socorro para a necessidade de mudança:

Minha terra porventura

Merece tal descrição

Lá a vida é menos dura

Qualquer um lhe estende a mão.

O céu é menos cinzento

Lá não tem poluição

Só existe um argumento

Que me parte o coração.

Ver o povo madrugar

E seguir para o roçado

Mas se a chuva não chegar

Perde o que se foi plantado.

Eu agora exilada

Só me resta descrever

Aqui não encontro nada

Que me motive a viver

Mas falar da minha terra

Ah isso me dar prazer.

E mesmo aqui tão distante

Tenho algo pra pedir

Quero agora nesse instante

Voltar para Manari

Linguagens \& Cidadania, v. 19, número especial, jan./dez., 2017. 


\section{Linguagens \& Cidadania}

Pois eu não quero morrer

Sem de lá me despedir. (1'23'’27',')

Pelos versos declamados, nota-se a maestria da aluna, não só por entender os problemas sociais de sua região, mas por registrá-los como uma verdadeira artesã das palavras, revelando criatividade e autoria na escrita, a partir de uma tessitura poética, que é mais que uma paródia do poema de Gonçalves Dias, mas uma esperança de libertação. Por meio dessa manifestação, ela explora os recursos facultados na língua e revela, portanto, refinado traço de letramento, tanto da letra como de mundo, o que deve ser considerado pelo professor no desenvolvimento de sua prática pedagógica.

\section{CONSIDERAÇÕES FINAIS}

Tendo em vista os depoimentos analisados a luz da sociolinguística educacional e levando em conta sua relação com as práticas de letramento na escola, é-se levado a crer que língua e sociedade são indissociáveis e que os discursos proferidos no documentário "Pro dia nascer feliz", de João Jardim, estão localizados em realidades sociocultural, ideológica e política que permitem enunciar algo a partir do contexto de onde os sujeitos estão inseridos.

Portanto, não se pode estigmatizar o educando, seja de escola pública ou mesmo privada, tampouco o professor pelos "seus dizeres", uma vez que todos esses partícipes do processo educacional, em um momento não monitorado, emitirão dialetos que revelam traços característicos de sua personalidade, localidade, ou seja, suas origens, além de revelar seus ideais, papéis sociais que desempenham e até de que geração fazem parte. Os usos que fazem da língua não devem ser vistos como "erros", mas como marcas linguísticas oriundas de seus diferentes níveis de letramento. Esse é, portanto, o grande desafio do educador, tendo como base uma pedagogia estratégica para a promoção do ensino.

Essa situação remete diretamente ao desafio do ensino de Língua Portuguesa na escola básica, respeitando os aspectos de variação linguística, como propõe os PCNs. Essa renovação pressupõe o reconhecimento linguístico e/ou linguageiro necessário ao espaço da sala de aula. Dessa forma, torna-se urgente a renovação do ensino, por meio da adoção de uma pedagogia 


\section{S Linguagens}

da língua materna, que substitua a precariedade da doutrina gramatical, até então ensinada nas escolas, a fim de que seja adotado um ensino plural para todos.

Para tanto, a escola precisa flexibilizar suas atitudes no tratamento dos textos e discursos, desenvolvendo um ensino de língua de forma contextualizada, integrando os saberes da gramática, da literatura e da produção de texto aos saberes vivenciados pelos alunos em seus contextos culturais específicos, o que constitui seus letramentos, no modelo ideológico (STREET, 1995). Desse modo, os alunos refletirão sobre as possibilidades de interação e sobre o uso crítico da pluralidade de manifestações linguísticas, sejam orais ou escritas.

Portanto, é preciso repensar o papel da escola, do profissional docente, seu processo de formação (inicial e continuada), redimensionando o pensar e o fazer de sala de aula, através de procedimentos metodológicos diferenciados e individualizados, que priorizem a aliança entre a teoria e prática, como forma de promover um aprendizado crítico-reflexivo da e sobre a língua, considerando os contextos sociais em que as práticas de ensino estão submetidas.

\section{REFERÊNCIAS}

ANTUNES, I. A língua e a identidade cultural de um povo. In: Língua, texto e ensino: outra escola possível. São Paulo: Parábola, 2009. p. 19-31.

BAGNO, M. Preconceito linguístico: o que é, como se faz. São Paulo: Loyola, 1999.

CAGLIARI, L. C. Alfabetização e Linguística. São Paulo: Scipione, 1999.

BORTONI-RICARDO, S. M. Educação em língua materna: a sociolinguística na sala de aula. São Paulo: Parábola, 2004. 2005.

Nós cheguemu a escola, e agora?: sociolinguística \& educação. São Paulo: Parábola,

BRASIL, Secretaria de Educação Fundamental: Parâmetros curriculares nacionais: terceiro e quatro ciclos do ensino fundamental: Língua Portuguesa. Brasília: MEC/SEF, 1998.

Ministério da Educação. Instituto Nacional de Estudos e Pesquisas Educacionais Anísio Teixeira. Sinopse estatística da educação básica: censo escolar 2004. Instituto Nacional de Estudos e Pesquisas Educacionais Anísio Teixeira. Brasília: O Instituto, 2003. Disponível em: 


\section{Singuagens}

< http://download.inep.gov.br/download/estatisticas/sinopse_estatistica_2004/Parte-1.pdf> Acesso em: 20 set. 2014.

CYRANKA. Lúcia F. M. Dos dialetos populares à variedade culta: a Sociolinguística na escola. Curitiba: Appris, 2011.

FERRAREZI JR., C. Pedagogia do silenciamento: a escola brasileira e o ensino de língua materna. São Paulo: Parábola, 2014.

KLEIMAN, A. Os significados do letramento: uma nova perspectiva sobre a prática social da escrita. Campinas: Mercado de Letras, 1995.

LABOV, W. Sociolinguistics Patterns. Philadelphia: University of Pennsylvania Press, 1972.

Padrões Sociolinguísticos. Tradução de Marcos Bagno. São Paulo: Parábola, 2008.

; HARRIS, W. A. De Facto Segregation of Black and White Vernaculars. In: SANKOFF, D. (org.). Diversity and Diachrony. Amsterdan, John Benjman, 1986.

MARCUSCHI, L. A. Da fala para a escrita: atividades de retextualização. 10. ed. São Paulo: Cortez, 2010.

PRO dia nascer feliz. Direção: João Jardim. Roteiro: João Jardim. Brasil. Produção: Flávio R. Tambellini e João Jardim. Copacabana filmes, documentário, 2006. DVD, drama, 87 min., color, $35 \mathrm{~mm}$.

SIGNORINI, I. Língua (em) e identidade: elementos para uma discussão no campo aplicado. Campinas: Mercado de Letras, 1998.

STREET, B. V. Social Literacies. Critical Approaches to Literacy in Development, Ethnography and Education. Harow: Pearson, 1995. 